Sign Systems Studies 30.1, 2002

\title{
Umwelt and semiosphere
}

\author{
Mihhail Lotman \\ Department of Semiotics, University of Tartu \\ Tiigi St. 78-310, Tartu 50410, Estonia \\ e-mail: mihhail@ehi.ee
}

\begin{abstract}
In the paper an attempt is made to treat the basic concepts of biosemiotics and semiotics of culture in a wide intellectual context. The three leading paradigms of the current intellectual discourse are distinguished, which could be conventionally designated as "classical", "modern" and "postmodern": Peirce's semiosis stands for the classical, Umwelt for the modern and semiosphere for the postmodern semiotic space.
\end{abstract}

I must start with an apology: although several biological and philosophical terms and constructions will be discussed, my paper is related to neither of those fields. One of the reasons is that I am a complete ignoramus in biology and allergic to philosophy. Thus, I will focus on the perspective of cultural semiotics, analysing the mentioned phenomena from the aspect which is close to Michel Foucault's archaeology of knowledge (Foucault 1970, 1972).

Before treating Jakob von Uexküll's Umwelt, we should briefly consider the intellectual context, where this concept appeared (so-tosay the Umwelt of Umwelt). In Darwinist world-view the key concept was environment: organism, life, evolution are its derivatives. It can be understood as if there was an environment, where an organism happens to be (the most exciting word in this sentence is to happen one should not think that life exists outside the environment, because environment itself produces life). So, in the beginning was the environment. The Darwinist conception was an organic product of the 
mentality of the given era: analogically, Newton's physics treats the relationship between object and space, Marxist philosophy the relationship between social system and social environment. Moreover, such paradigm seems to be fully natural so far and in correspondence with the common sense. Anyway, until now it has been the basis for most critical remarks towards the Yuri Lotman's conception of semiosphere. Even the classical cybernetics proceeds also from the same idea. The key question for Norbert Wiener was the adaptation of the system with its environment (but at the same time, through the mechanism of feedback the system could actively influence environment as well).

In such perspective Jakob von Uexküll's Umwelt seems to be completely strange and extravagant: for him primary is organism which produces its Umwelt; everything has its own Umwelt according to its specific measures (Uexküll 1928). One could pass Uexküll's conception as the eccentricity of a provincial semidiletant, but we can find here certain interesting parallels with other fields. Here it would be sufficient to mention Einstein's cosmology and Heidegger's philosophy. For Einstein, time and space are not basic and independent entities, to what matter has come somehow. Time-space is the function of the matter, and that applies to Heidegger as well: not the existence is "located" in time and space, but it creates them itself (I mean here above all Sein und Zeit and his works in the field of art philosophy, as, e.g., Die Frage nach dem Ding; Heidegger 1993, 1976).

I would like to point out that we are not dealing here with just terminological differences - we cannot just replace environment with Umwelt; the difference between these notions is not even conceptual, but paradigmatic: a completely different idea of life, organism, evolution, biology itself evolves - biology becomes a discipline of semiotic cycle, since it can be shown that in the conception of Umwelt inevitably appears the problem of meaning.

Yuri Lotman's cultural semiotic works initially proceeded from the paradigm which is very similar to that of Uexküll's. In the function of organism he had text, the analogy of Umwelt was context. Unlike earlier linguistic and semiotic ideas (e.g. Saussure's and Jakobson's) the context for Lotman does not precede text, being its preliminary condition, but, vice versa, text produces its context in the widest sense, including all the participants in the communicative act (Lotman 
1982, 1990; M. Lotman 2000). But it seems that such extreme paradoxicality (cf. the circumstance that an author does not create text - text creates an author) did not disturb Lotman: he does not conceal it, but tries to make it even stronger. ${ }^{1}$ In his late works he formulates the conception of semiosphere, the basis of which is so-to-say the crisis of identity: for its own existence every semiotic entity (sign, text, mind, or culture as a whole) needs the other. It applies to the synchrony as well as diachrony: sign, text, culture can exist only among other signs, texts, cultures and they must be preceded by other signs, texts, cultures.

In his earlier works Lotman formulates the three most important functions of text, reason, and culture. These are: (1) communicative, i.e. the transmission of already completed messages (it is important here for an author to know how to formulate his message adequately and for a reader to know how to understand it adequately); (2) memorial; (3) creative: the production of new messages. In his late works it reveals that it is impossible to carry out any of these functions without the other. Although Lotman refers here, on the one hand, only to Ilya Prigogine and, on the other hand, to Kant and Leibniz (Lotman 1997; Prigogine, Stengers 1984), another intellectual context is obviously here even more important — so-called dialogical school. Of course, Mikhail Bakhtin's ideas were always essential for Lotman, but here it would be perhaps more useful to refer to Martin Buber, as well as to Emmanuel Lévinas, especially, since he was not familiar with their works (particularly with the latter one's). In my opinion, Buber and Bakhtin were more profound thinkers, but I would like to deal here with Lévinas, since he is philosophically more accurate. Lévinas shows that there is a mistake in Heidegger's system: an isolated existence is not possible in ontological, as well as in existential level: for its own existence an existent needs the other. Meeting the other

${ }^{1}$ Somewhat similar conclusions were also made by French structuralists Roland Barthes and Michel Foucault, who declared the death of the author. The difference from Lotman's conception was not only conceptual, but, above all, psychological. For French scholars the history of culture is primarily a constant decrease, creation is consumption (cf. above all Georges Bataille's "Literature and evil"; no wonder that a creation kills its creator; Bataille 1990). For Lotman, it is rather a myth of Galatea: Pygmalion does not have to die. 
becomes crucial event for existence, or more correctly, it evolves just then (Levinas 1976).

But here, inevitably, a question arises: who is the other? If we approach him with certain presentiments, suppositions a priori, etc, then it would be not a real meeting, but projecting qualities, experiences, etc of one's own. A real meeting would be possible only if we were dealing with an internal readiness to meet absolutely the other (i.e. also with somebody for whom it would not be meeting or event at all).

I would like to make a remark here. On the occasion of Lévinas we are not dealing with only intellectual, but as well with psychological boldness, since his conception was formed during the war, when he was a German prisoner, and published in 1947, when he knew that all his relatives in Lithuania were terminated namely by those who were not willing to meet the other. But even this experience and perhaps in the first place this experience decided his firmness. What Lévinas intends to say here is that we live in the world without guarantees and meeting the other is always not only risk, but deadly risk, but it is the risk, which is existentially important for us (it is not accidental that meeting with the other is on Lévinas' occasion preceded by death). Even if we do not agree with Lévinas in so-to-say conceptual level, we must appreciate his intellectual courage.

Nevertheless, Lévinas' phenomenological language which seems to be mighty and adequate enough to define the existential necessity of the existence of the other can not in principle transmit the content of meeting. In order to that we must return to Buber, who summarized it with a simple phrase: "you and me". As Émile Benveniste showed, such words as "me", "you", "here" and "now" differ from usual words which signify objects not because they are different words, but because they belong to a principally different sign system. Benveniste tried to mark this differentiation by using such terms as semiotics and semiology, as well as speech and language. Namely, deictic words are the ideal form of semiotics of speech, differently from semiotics of language which is oriented towards objects and situations (Benveniste 1966). It is a very important differentiation, although in my opinion not quite adequate: deictic signs belong to the field of speech as well as symbolic ones. But here is another aspect which was overlooked by Benveniste: we are not dealing here just with speech (i.e., e.g., with 
monological speech), but necessarily with dialogue. Beyond the situation of dialogue deictic words are just meaningless.

For Buber and Bakhtin "me" and "you" appear to be the products of dialogue and dialogue turns out to be an existential notion: without "you", who is in dialogue with "me", there is no "me" either. (Buber 1970, Бахтин 1975, 1998). Therefore, "me" and "you" are not constants, but variables; although for him also the participants of dialogue are indivisible entireties.

The participants in a dialogue are not impartial personages "they", but "you" and "me", i.e. the only adequate sight to a dialogue is from inside. As for such words as "you" and "me", then their peculiarity is that they do not mean anything a priori, they have no significatum at all. "You" are the one, whom "I" call "you" and "I" am the one for whom "you" are "you". This situation can not be interpreted in terms of deterministic logic, since we are dealing here with an obvious paradox: "you" are the precondition of "my" existence, i.e. "you" must exist before "me". At the same time "you" fully depend on "me". Hence Buber makes a conclusion of existential essence of dialogue. Buber and Bakhtin relate space to dialogue. The space of dialogue does not exist a priori, it is being created in the course of dialogue.

One of the most important special features of Tartu semiotic school is that simple semiotic systems are not treated as prime elements, from which more complicated systems are formed, but vice versa: elementary semiotic systems are abstractions, simplicity means here simplification. From the viewpoint of semiosis, semiosphere as a whole is the initial unit which is divided into simple subordinate systems. In this respect Tartu semiotics differs in principle from Peirce's semiotics, the centre of which is (single) sign and its qualities; sign in Tartu semiotics is not something which has been given immediately, but the product of analysis.

While originally the conception of secondary modelling systems (as the name itself reflects) at least potentially enabled to treat natural language as an initial system, then Yuri Lotman in his works of the 1980 s treated the verbal, so-called usual communication as a polyfactorial multilingual activity. In this sense each verbal text as well contains several messages which have been created in different languages. Minimal pair of languages would be what Lotman called 
(not quite accurately) symbolic and iconic; the first of them is described by the grammar of natural language, the other by rhetorics. Rhetorics for Lotman is, first of all, a tool for translating (visual) images into verbal text. In the case of a narrative text also the narrative structure as a specific language must be added here. But it would be incorrect to assume that the logical structure of language, images and narrative are primary entities which exist before language and beyond text. Imagological structure depends not only on the imaginable objects, but as well on the language to which they have been coded. The same applies as well to narrative (Lotman 1992).

Every act of communication includes an element of dialogue, translation and creativity, whereby dialogue begins already in the addresser, the speaking subject is not elementary from the communicative aspect. Even the translation inside the human brain comes close to artistic translation.

Thus, semiosphere is not just new concept, but as Umwelt demands new paradigm, new logic, which is based not on determinism, but on dialogue.

We can summarize the whole thing with the following schema (which is, of course, schematic):

\begin{tabular}{|l|l|l|l|}
\hline cosmology: & Newton & Einstein & Prigogine \\
\hline life: & environment & umwelt & semiosphere \\
\hline philosophy: & Hegel/Marx & Heidegger & Buber/Bakhtin \\
\hline discourse: & "classic" narrative & "modern" narrative & dialogue \\
\hline
\end{tabular}

Classic narrative is based on causal and temporal relationship; modern abandons causality as well as temporality, and as a result, e.g., a spacial form (described by Joseph Frank 1963) evolves (e.g., James Joyce and Marcel Proust).

We might add to this (schema) dissenting ideas of truth: it is a priori in Newton's world, relative in Einstein's world, and, e.g., in the paradigm of analytical philosophy it is better not to speak about truth at all, but to avoid falsehood and nonsenses: one could reach truth through the combination of unfalse sayings. And finally, in dialogical logics truth is not only a posteriori, but cooperative as well: it arises in dialogue and can be preserved only in the environment of dialogue, i.e. every petrified formulation is deadly for truth. 


\section{References}

Bataille, Georges 1990. La littérature et le mal. Paris: Gallimard.

Benveniste, Émile 1966. Problèmes de linguistique générale. Paris: Gallimard.

Buber, Martin 1970. I and Thou. A new translation with prologue "I and you" and notes by Walter Kaufmann. New York: Simon \& Schuster.

Foucault, Michel 1970. The Order of Things: An Archaeology of the Human Sciences. New York: Vintage.

- 1972. The Archaeology of Knowledge. New York: Pantheon.

Frank, Joseph 1963. Spatial form in modern literature. In: Frank, Joseph, The Widening Gyre: Crisis and Mastery in Modern Literature. New Brunswick: Rutgers University Press.

Heidegger, Martin 1967. What Is A Thing? Barton, W. B. Jr.; Deutsch, Vera (trans.). Chicago: Henry Regnery Company.

- 1993. Sein und Zeit. 17te Aufl. Tübingen: Max Niemeyer Verlag.

Lévinas, Emmanuel 1976. Humanisme de l'autre homme. Montpellier: Fata Morgana.

Lotman, Juri M. 1975. The discrete text and iconic text: Some remarks on the structure of narrative. New Literary History 6(2): 333-338.

- 1982. The text and the structure of its audience. New Literary History: A Journal of Theory and Interpretation 14(1): 81-87.

- 1990. Universe of the Mind: A Semiotic Theory of Culture. Shukman, Ann (trans.); Eco, Umberto (introd.). London: I. B. Tauris \& Co Ltd.

- 1997. Culture as a subject and an object in itself. Trames 1(1): 7-16.

Lotman, Mihhail 2000. A few notes on the philosophical background of the Tartu School of semiotics. European Journal of Semiotic Studies 12(1): 23-46.

Prigogine, Ilya; Stengers, Isabelle 1984. Order out of Chaos. Toronto: Bantam Books.

Uexküll, Jakob von 1928. Theoretische Biologie. Berlin: Springer.

Бахтин, Михаил 1975. Вопросы литературы и эстетики. Москва: Художественная литература.

- 1998. Тетралогия. Москва: Лабиринт.

Лотман, Ю. М 1992. Культура и взрыв. Москва: Гносис.

\section{Umwelt и семиосфера}

В статье делается попытка анализа базовых понятий биосемиотики и семиотики культуры в контексте интеллектуальных стратегий. Выделяются три ведущих интеллектуальных дискурса современности, условно обозначаемые как "классический”, “модерный” и “постмодерный”: пирсовский семиозис маркирует классическую трактовку семиотического пространства, Umwelt Я. Юкскюлля - модерную, семиосфера - постмодерную. 


\section{Omailm ja semiosfäär}

Artiklis tehakse katse käsitleda bio- ja kultuurisemiootika baasmõisteid laias intellektuaalses kontekstis. Eristatakse kolm juhtivat paradigmat nüüdisaegses intellektuaalses diskursuses, tinglikult võiks neid tähistada kui "klassikaline", "modernne" ja "postmodernne": Peirce'i semioos tähistab klassikalist semiootilist ruumi, Umwelt — modernset, semiosfäär — postmodernset. 